\title{
CHILE, PERU, AND THE \\ CALIFORNIA GOLD RUSH \\ OF \\ 1849
}




\section{Books Written by Jay Monaghan}

Lincoln Bibliography, 1839-1939 (2 volumes)

Diplomat in Carpet Slippers: Abraham Lincoln

Deals with Foreign Affairs

Last of the Bad Men: The Legend of Tom Horn

The Overland Trail

This is Illinois: A Pictorial History

The Great Rascal:

The Life and Adventures of Ned Buntline

Civil War on the Western Border, 1854-1865

The Man Who Elected Lincoln

Swamp Fox of the Confederacy:

The Life and Military Services of M. Jeff Thompson

Custer: The Life of General George Armstrong Custer

Australians and the Gold Rush:

California and Down Under, 1849-1854

\section{Books Edited by Jay Monaghan}

John Hope Franklin, Civil War Diary of James T. Ayres

Robert L. Kincaid, The Wilderness Road

Philip D. Jordan, The National Road

John Drury, Old Illinois Houses

Theodore Calvin Pease, Story of Illinois

Francis Philbrick, Laws of Illinois Territory, 1809-1818

Mary Waters, Illinois in the Second World War

The Book of the American West

R. B. Townshend, A Tenderfoot in Colorado

The Private Journal of Louis McLane, U.S.N., 1844-1848 


\section{Jay Monaghan}

\section{CHILE, PERU,}

\section{AND THE}

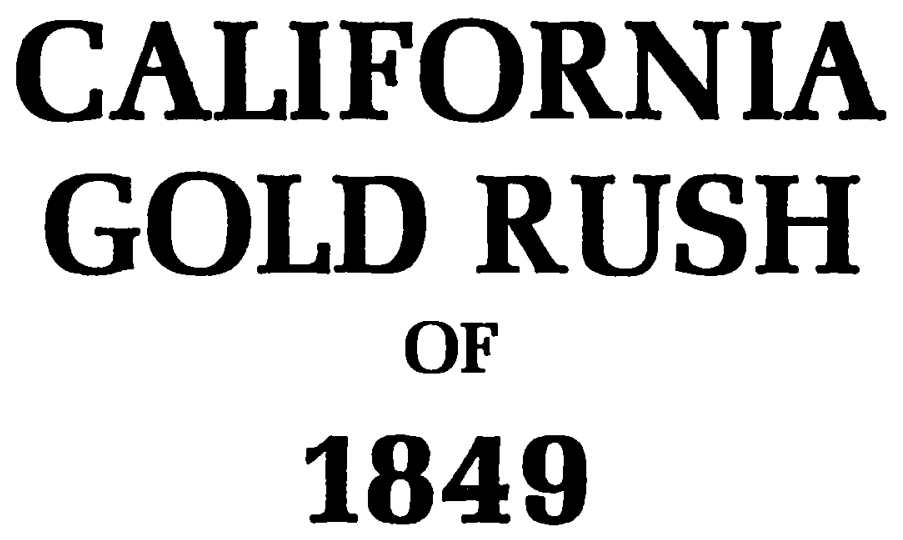

UNIVERSITY OF CALIFORNIA PRESS Berkeley Los Angeles London 1973 
University of California Press

Berkeley and Los ANgeles, California

University of California Press, Ltd.

LONDON, ENGLAND

Copyright (C) 1973 by The Regents of the University of California

ISBN: 0-520-02265-3

Library of Congress Catalog Card Number: 72-78946

PRINTED IN THE UNITED STATES OF AMERICA 


\section{For Mildred, encore une fois}


